\title{
Impact of anthropogenic actions on the quality of the Maâmora groundwater (Tiflet city region)
}

\author{
Anass QOUTBANE ${ }^{*}$, Essediya CHERKAOUI, Mohamed KHAMAR and Abderrahman NOUNAH \\ Civil Engineering and Environment Laboratory (LGCE), Team Materials, Water and Environment Higher School of \\ Technology, Mohammed V University in Rabat
}

\begin{abstract}
The quality of groundwater in and around the city of Tiflet depends mainly on the various anthropogenic impacts on ecosystems where the Maamora groundwater in this region is subject to liquid discharges from the city of Tiflet from Oued Tiflet and infiltration of leachate from the uncontrolled landfill. With the ultimate aim of considering the necessary solutions and ensuring the means of protecting water resources and sustainable development of the Tiflet region, the study of the physical, chemical and bacteriological quality of groundwater (Maamora groundwater) from the city of Tiflet to the centre of the commune of Sidi Boukhelkhal, which is located north-west of the city and on the banks of Oued Tiflet, is the first step. These results are processed by ArcGis software and presented by interpolation maps. The bacteriological characterization of groundwater shows that it is not drinkable but acceptable for agricultural use, however, physico-chemical parameters such as nitrates and sulphates remain below the quality standards for human consumption. Turbidity, $\mathrm{pH}$ and conductivity vary according to space but also do not exceed quality standards in irrigation and human consumption.
\end{abstract}

\section{Introduction}

Water is defined as a vital substance for all living things. Once it is polluted or contaminated by different sources of pollution, it leads to the spread of several diseases such as gastroenteritis, viral hepatitis, typhoid, leptospirosis. Millions of infants and children die each year from diarrhoeal diseases caused by contaminated food or drinking water. $[1,2,3]$

Morocco has very important water resources: groundwater, rivers and two oceanic facades with $3500 \mathrm{~km}$; a wealth of plant, animal and fish species likely to ensure the country a solid foundation for a real economic take-off and a sustainable and harmonious human development. However, population growth and the rate of urbanization have had a negative impact on ecosystems.

In addition, the unreasonable management of these natural resources, the dumping of solid waste and liquid discharges into the natural environment without any treatment, illegal landfills and the lack of fundamental notions of environmental protection among citizens, jeopardize the country's environmental stability.

The city of Tiflet, in this case, is one of the Moroccan cities that does not have a wastewater treatment plant or a controlled landfill, which is a priori involved in the deterioration of the groundwater table, through the infiltration of leachate and chemicals from pesticides used in agricultural activities.

The objective of this work is to highlight water quality and identify sources of disturbance, based on the spatial factor, of groundwater of the
Maamora groundwater from the city of Tiflet to the centre of Sidi Boukhelkhal and its surroundings by means of bacteriological and physico-chemical parameters.

\section{Materials and methods}

\subsection{Study site}

The city of Tiflet (Fig. 1) is a Moroccan city, located $56 \mathrm{~km}$ from the capital Rabat, dependent on the province of Khemisset in the Rabat-SaléKenitra region.

The population of Tiflet is 86709 inhabitants and covers an area that tends to be around $12 \mathrm{~km}^{2}$. The city is affiliated to the two catchment areas, Sebou and Bouregreg and has two water resources, the Oued de Tiflet and the Maamora groundwater, which are used in agriculture, which is defined as the city's main economic activity with a UAA of 67 ha, livestock farming comes second, a dominant sheep activity estimated at $97.2 \%$. [4]

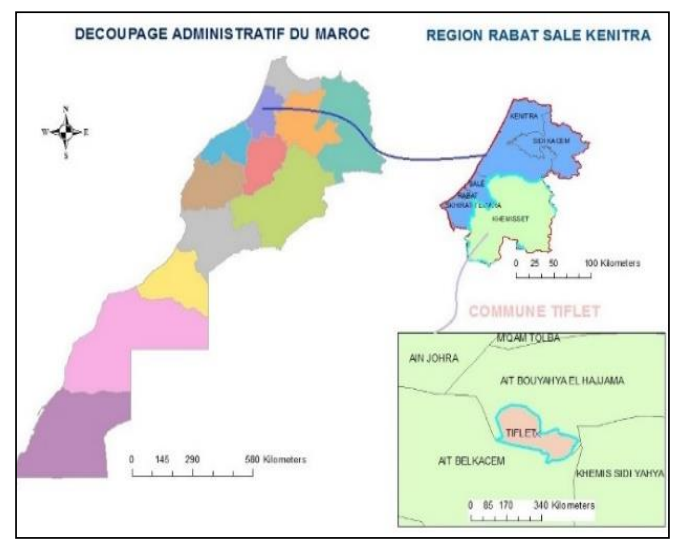

Fig. 1. Geographical location of the city of Tiflet

Corresponding author: qoutbaneanass@gmail.com 


\subsection{Geology and hydrogeology of the study site}

Our study area is geologically part of the Khemisset-Tiflet region, which is located between the meseta that was structured during the hercynian phase. It extends over the geological provinces of the Sehoul block in its western part (Tiflet region) while most of it lies to the south of the Pre-Rife Wrinkles [5]

In addition, it belongs to a domain with the same litho-stratigraphic facies as the neighbouring hydrogeological units (North of Maâmora and Northwest, Rharb in the North East and Meknes Basin in the East) [7].

However, from a hydrogeological point of view, our study site is part of the Maâmora groundwater, which is bounded by the Rharb groundwater as its western boundary and by the Fés-Meknès corridor as its eastern boundary. [6]

In addition, the Mâamora aquifer in the Tiflet region is characterized by the presence of two superimposed aquifers:

- The water table which circulates in alluvial formations of the Villafranchien made up of sand, sandstone and limestone.

- The deep-water table made up of limestones from the Lias and separated from the surface water table by Miocene age marl formations. [8]

\subsection{Sampling}

We have taken groundwater from the Maamora groundwater from 36 wells located along the city and its surroundings (rural communes) and the commune of Sidi Boukhelkhal over a length of approximately $40 \mathrm{~km}$ and an area of approximately $360 \mathrm{~km}^{2}$ (Fig. 2)

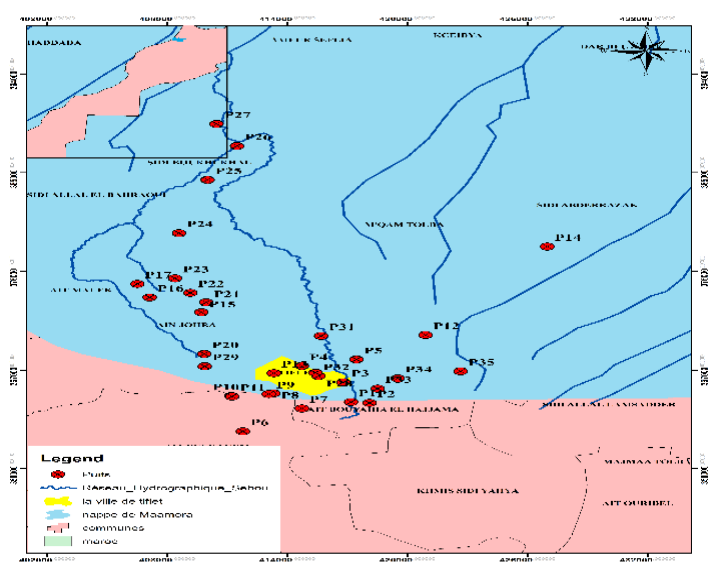

Fig. 2. Geographical location of groundwater abstraction wells

The piezometric level of the wells studied increases from the town of Tiflet and its surroundings to the northwest where the groundwater level varies between $100 \mathrm{~m}$ and 400 m above sea level. (Fig. 3)

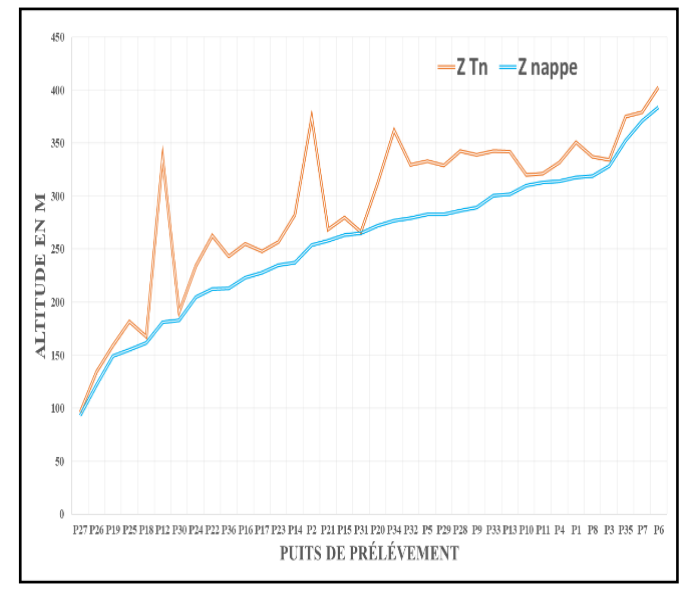

Fig. 3. Piezometric level of the wells studied

\subsection{Groundwater analysis techniques}

In order to determine the quality of the groundwater in the Tiflet region and its surroundings, we carried out physico-chemical and bacteriological analyses.

The $\mathrm{pH}$ and temperature were determined by a 206 Lutron $\mathrm{pH}$ meter equipped with a temperature sensor.

The electrical conductivity was measured using a WTW LF90 conductivity meter. Turbidity was determined by a portable $2100 \mathrm{p}$ turbidimeter.

Suspended solids (SS) are determined by filtering a volume of water on a $\mathrm{GF} / \mathrm{C}$ membrane $(0.45$ micron). The mineral material was calculated by drying the sample at $550^{\circ} \mathrm{C}$ in porcelain capsules first weighed and reweighed after drying and the organic material was measured by evaporating the sample at $105^{\circ} \mathrm{C}$ in porcelain capsules first weighed and reweighed after drying. [8]

The water hardness was determined by complexometry by making a volumetric determination of $50 \mathrm{ml}$ of the sample with a complexing titrant, EDTA in the presence of a buffer solution and the NET colour indicator. The TAC (full alkali titre) was determined from the $100 \mathrm{ml}$ volumetric assay of the sample with 0.02 mol.1-1 acid to $\mathrm{H} 3 \mathrm{O}+$ ion in the presence of helianthin. [8]

Nitrates NO3- are determined by the spectrophotometric method in the presence of sodium salicylate and read at $450 \mathrm{~nm}$ wavelength. Sulphates are measured by the nephelometric method in hydrochloric medium as Barium sulphate and Tween solution and read out over a wavelength of $650 \mathrm{~nm}$. Phosphates are calculated by the spectrophotometric method in the presence of the ammonium molybdate reagent and read at wavelength $880 \mathrm{~nm}$. [8] 
Microbiological analyses were limited to the determination of indicators of faecal pollution (faecal coliforms and faecal streptococci).

Fecal coliforms are determined by filtering water on a membrane which is then deposited on TERGITOL medium and incubated at $44^{\circ} \mathrm{c}$ for 48 h.

Fecal streptococci are determined by filtering water on a membrane which is then placed on SLANETZ medium and incubated at $37^{\circ} \mathrm{C}$ for 48 hours. [8]

\section{Results and discussions 3.1. Physico-chemical quality}

The physico-chemical analyses of the groundwater studied remain quite variable from one parameter to another.

Thus, the $\mathrm{pH}$ varies between 6.47 and 7.66. These values comply with the standards for water intended for human consumption on the one hand and with the standards for water intended for irrigation on the other hand. $[9,10]$

The conductivity of these waters is gradually decreasing from the town of Tiflet to the northwest while an increase is observed to the northeast.

The recorded conductivity values range from a minimum of $640.1 \mathrm{~S} / \mathrm{cm}$ to a maximum of 9232

$\mathrm{S} / \mathrm{cm}$ measured at well number 13 in the commune of Sidi Abderrazak. (Fig. 4).

According to the simplified grid for assessing overall groundwater quality, the results show that $36.4 \%$ of wells are of good quality, $48.48 \%$ are of medium quality, $3 \%$ are of poor quality and $12.12 \%$ are very poor. [11]

In general, $75.65 \%$ of the wells studied have conductivity values below the conductivity limit value for water intended for human consumption, given by drinking water standards, and $100 \%$ of the wells do not exceed the maximum value set by the quality standard for water intended for irrigation. $[9,10]$

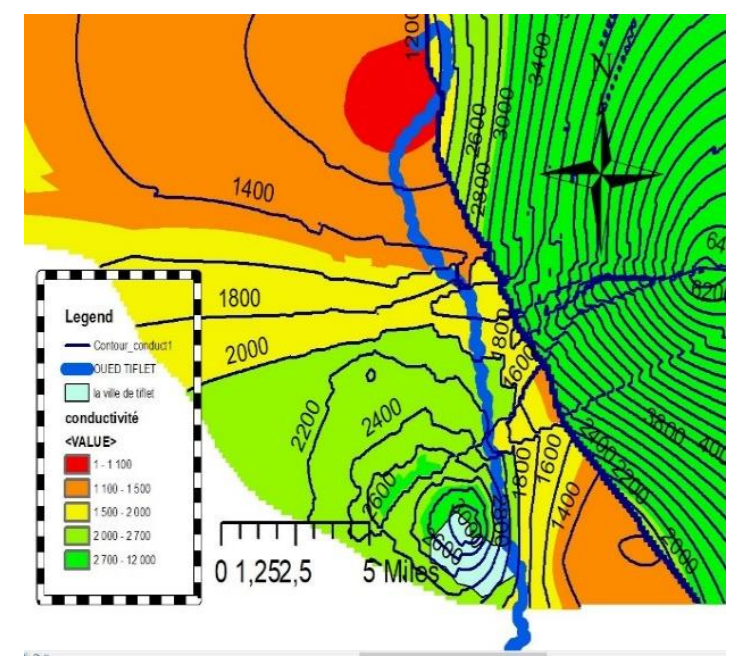

Fig. 4. Spatial variation of conductivity in the study area

Water turbidity ranges from 0.15 NTU to 51.3 NTU. However, $90 \%$ of the wells do not exceed the turbidity limit set by the drinking water quality standard. (Fig. 5) [9]

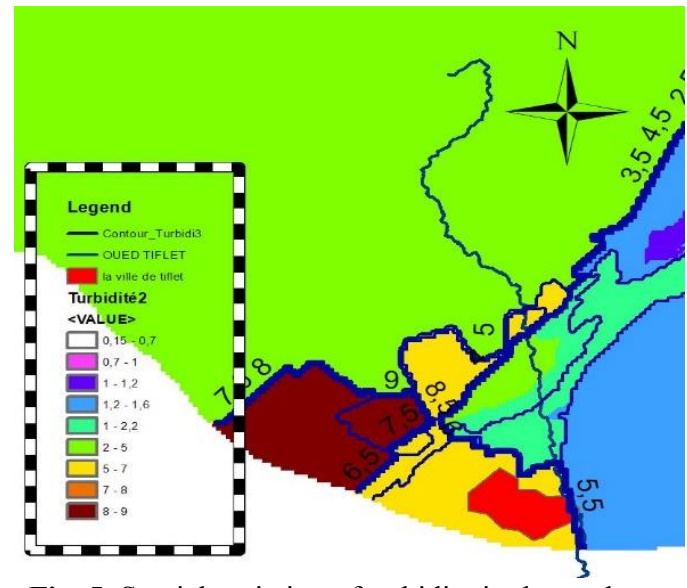

Fig. 5. Spatial variation of turbidity in the study area

The content of suspended matter is highly variable with a minimum value of $3 \mathrm{mg} / \mathrm{l}$ and a maximum value of $1100 \mathrm{mg} / \mathrm{l}$ recorded in the commune of Sidi Boukhelkhal. (Fig. 6)

According to the quality standards for water intended for irrigation, this water remains acceptable for irrigation (gravity irrigation system). [10]

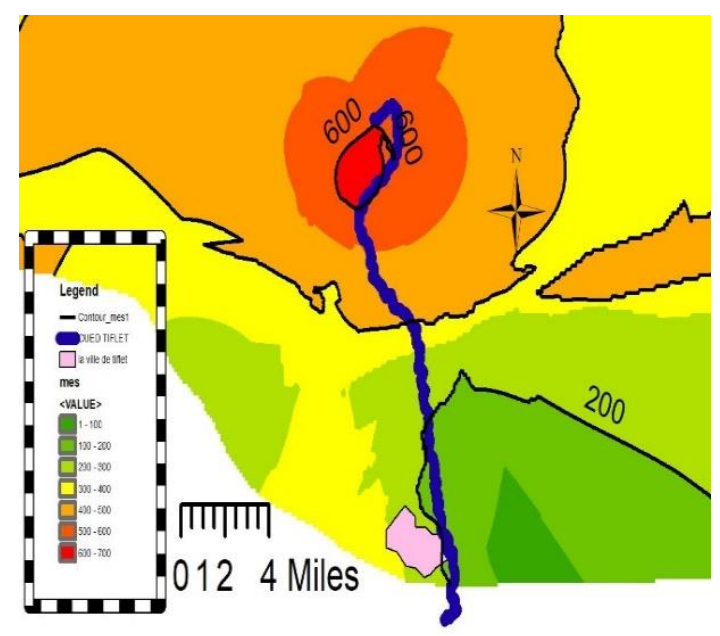

Fig. 6. Spatial variation of TSS in the study area

As for mineral matter, the values recorded in the waters studied vary from $1 \mathrm{mg} / 1$ to $24.15 \mathrm{~g} / \mathrm{l}$. The highest concentrations are observed in the southern part of the study area. While the level of organic matter varies between $3 \mathrm{mg} / \mathrm{l}$ and $17.63 \mathrm{~g} / \mathrm{l}$.

The water hardness calculation shows that $100 \%$ of the wells studied are very hard since they exceed $30^{\circ} \mathrm{F}$. [12]. (Fig. 7) 


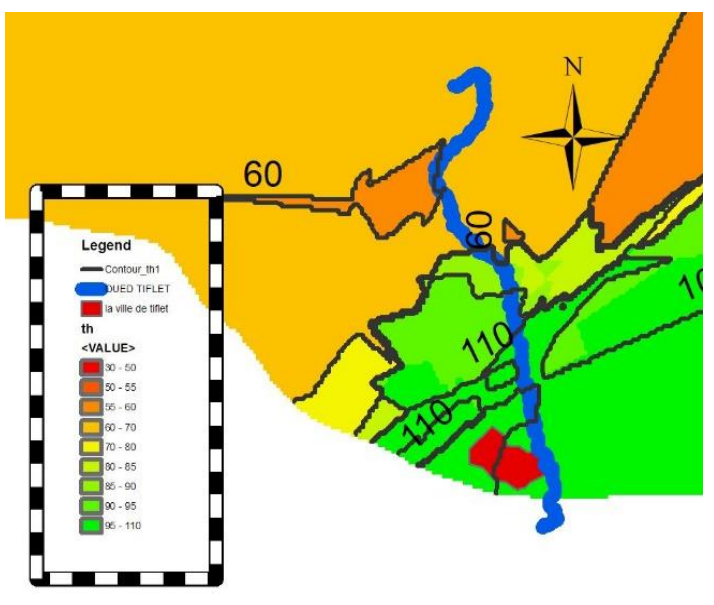

Fig. 7. Spatial variation of the total hardness in the study area

The nitrate concentration fluctuates between 0.29 $\mathrm{mg} / \mathrm{l}$ and $117.34 \mathrm{mg} / \mathrm{l}$. The lowest concentrations are found in the municipality of Sidi Boukhelkhal. According to the simplified grid for assessing the overall quality of groundwater, $33.33 \%$ of wells are of excellent quality, $12.12 \%$ of wells are of good quality, $51.55 \%$ of wells are of medium quality and $3 \%$ of wells are of poor quality. [11] According to our results, $88 \%$ of the wells studied do not meet the limit value for nitrate concentration in drinking water set by the quality standard, which is limited to $50 \mathrm{mg} / \mathrm{l}$. [9]

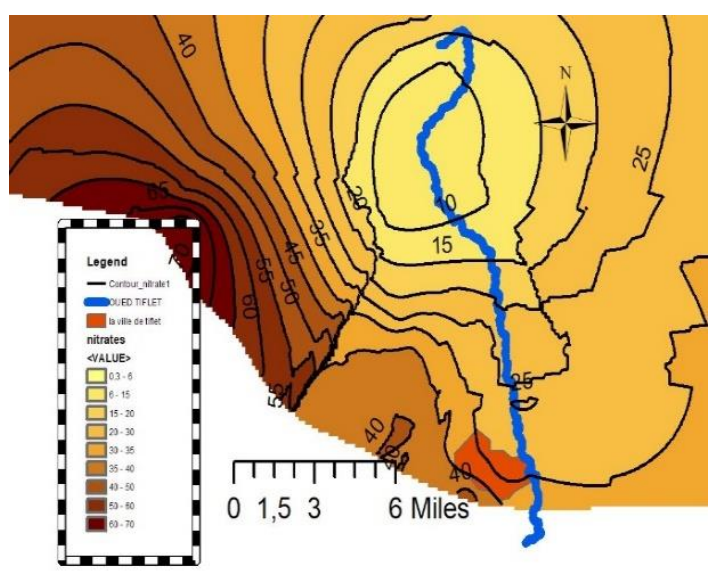

Fig. 8. Spatial variation of nitrates in the study area

The concentrations of sulphates collected from the wells analyzed range from $0.89 \mathrm{mg} / 1$ to $47.99 \mathrm{mg} / \mathrm{l}$. These values are consistent with the maximum values set by drinking water quality standards and for water intended for irrigation. 9, 10] (Fig. 9)

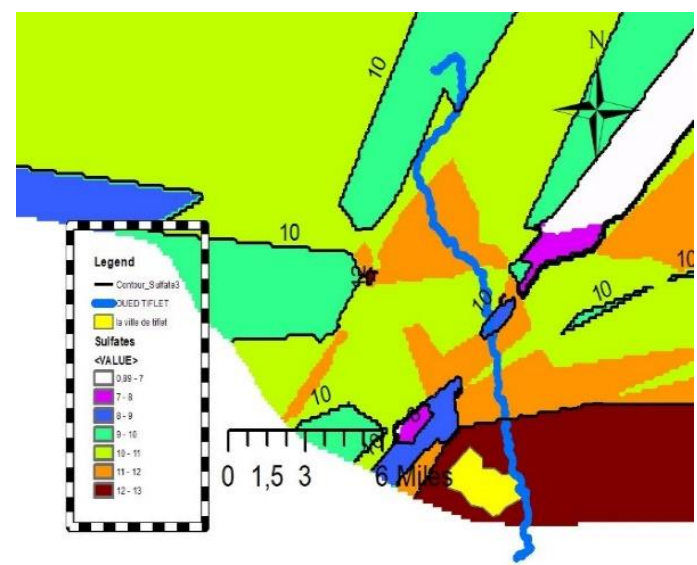

Fig. 9. Spatial variation of sulphates in the study area

As shown in the following figure, the concentration of phosphates in groundwater changes from $0 \mathrm{mg} / \mathrm{l}$ (24\% of wells) to $4 \mathrm{mg} / \mathrm{l}$. (Fig. 10). The low phosphate concentration can be explained by the ease with which phosphates can be fixed by the soil. [13]

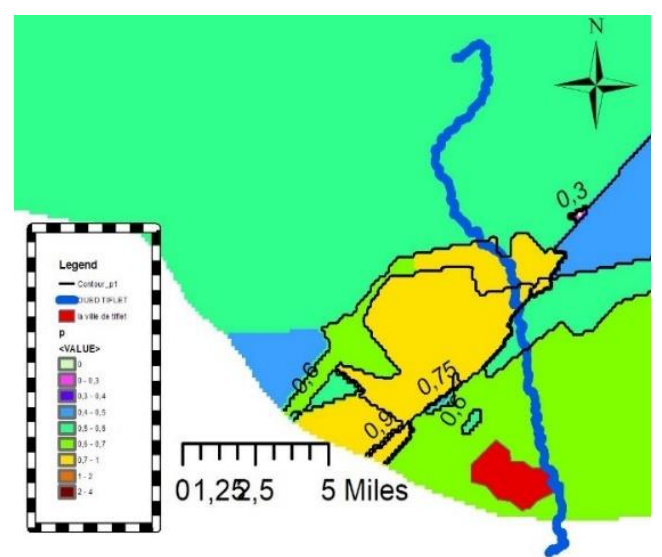

Fig. 10. Spatial variation of phosphates in the study area

\subsection{Bacteriological quality}

From a bacteriological point of view, the groundwater of the city of Tiflet and its regions are found not to be drinkable as a whole since they exceed the value set by the Moroccan standard for the quality of water intended for human consumption, this is reflected in the high concentrations of faecal coliforms, which generally exceed $65 \mathrm{CFU} / 100 \mathrm{ml}$, (Fig. 11) and faecal streptococci, which generally exceed 70 CFU/100 ml (Fig. 12). On the other hand, this bacteriological quality remains acceptable for use in irrigation according to the quality grid for water intended for irrigation. [9, 10] 
By way of comparison, the bacteriological quality of the groundwater in the city of Tiflet; dependent on the Maamora groundwater; is good compared to the quality of the groundwater in the Martil groundwater table, which exceeds $1000 \mathrm{CFU} / 100$ ml. [14]

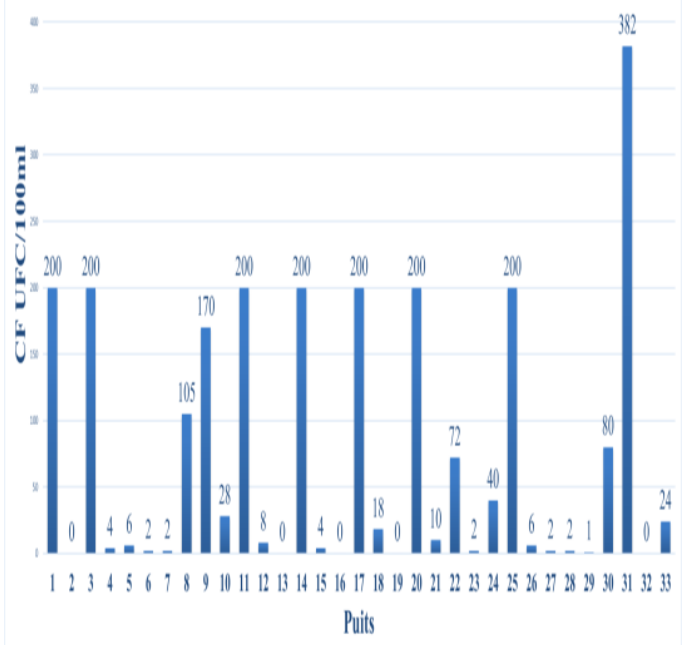

Fig. 11. CF concentration of the wells analysed

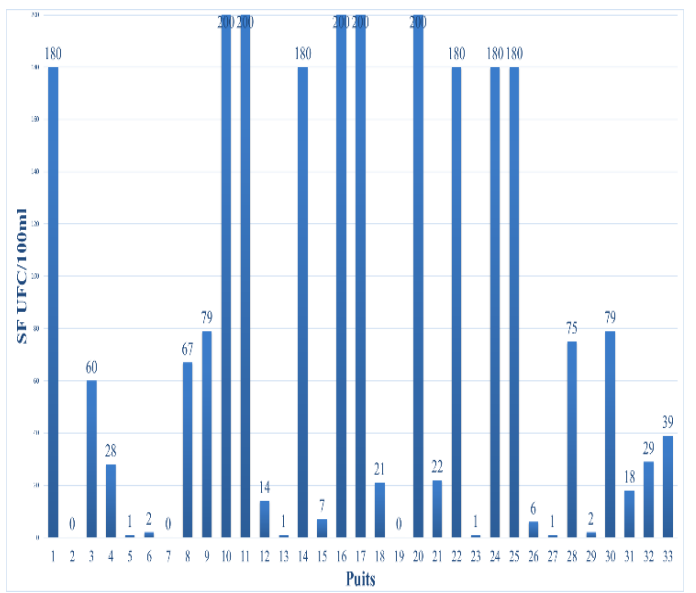

Fig. 12. SF concentration of the wells analysed

\subsection{Discussion of the results}

Several studies and analyses have been carried out at the national level to determine the quality of groundwater from different Moroccan aquifers, to this end we compare the results obtained at the Maamora aquifer (in the city of Tiflet) and the aquifers of the provinces of Taza, Martil, Settat, Mohammedia, Temara, Dar Bouazza, Tadla and the Central High Atlas.

Taking into account our results, the electrical conductivity of Tiflet's groundwater is lower than that of the groundwater in Taza province (5010 $\mathrm{s} / \mathrm{cm}$ ), the Mzamza Chaouia community (3002 $\mathrm{s} / \mathrm{cm})$, and Tadla $(4092.36 \mathrm{~s} / \mathrm{cm})$, while it is higher than that of the Central High Atlas (1640.03 s/cm). (Fig 13) [15, 17, 18, 19]

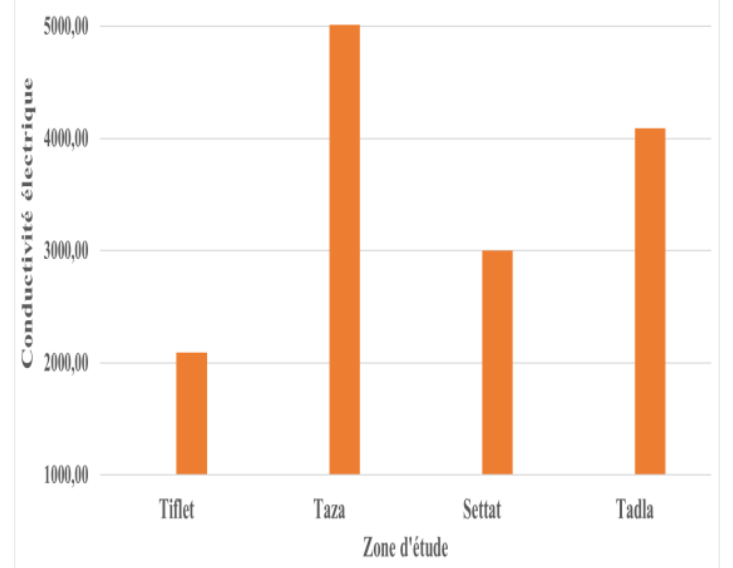

Fig. 13. Conductivity measurement at different groundwater levels in Morocco

The temperature variation remains discrete, since the values recorded range from $18^{\circ} \mathrm{C}$ to $25^{\circ} \mathrm{C}$. Generally the temperature varies according to the climate of the region.

The turbidity of the Tiflet groundwater is 9 times the turbidity measured at the Mohammedia, Temara and Dar Bouazza groundwater level (2 NTU), on the other hand the hardness retained is almost twice the hardness referenced at the Tadla groundwater level $\left(137.38^{\circ} \mathrm{F}\right)$. [16, 17]

The alkalinity of the water is high in the region from Mzamza to Settat $\left(77.75^{\circ} \mathrm{F}\right)$, where it is more than ten times the alkalinity measured at Tiflet and twice the alkalinity measured at Tadla $\left(31.20^{\circ} \mathrm{F}\right)$. $[17,19]$

However, organic matter varies greatly between Tadla groundwater, which is $3083.88 \mathrm{mg} / \mathrm{l}$, Maamora groundwater at Tiflet, which is $950 \mathrm{mg} / \mathrm{l}$, and Taza groundwater, which is $2.37 \mathrm{mg} / \mathrm{l}$. [15, 17]

The concentration of nitrates in water varies from one region to another. The area of the Central High Atlas has the lowest concentration $16.49 \mathrm{mg} / \mathrm{l}$, compared to the region of Tiflet 32.66, Tadla 44 $\mathrm{mg} / \mathrm{l}$, Mohammedia and Dar Bouazza $100 \mathrm{mg} / \mathrm{l}$

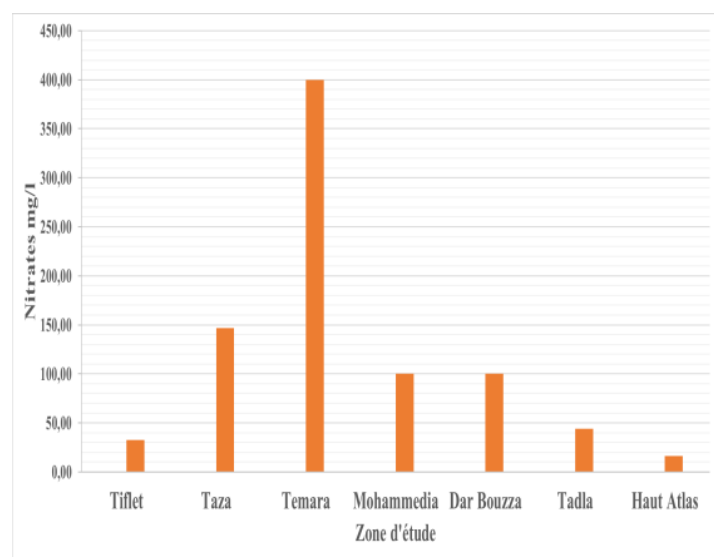


Taza $147 \mathrm{mg} / \mathrm{l}$, Temara $400 \mathrm{mg} / \mathrm{l}$ (Fig 14). $[15,16,17,18]$

Fig. 14. Nitrate concentration at different slicks in Morocco

The concentration of sulphates in the groundwater of the city of Tiflet remains lower than that of groundwater in the Settat region $(490.83 \mathrm{mg} / \mathrm{l})$ and in the Tadla area $(179.34 \mathrm{mg} / \mathrm{l}) .[17,19]$

\section{Conclusion}

The physico-chemical and bacteriological quality of the groundwater of the city of Tiflet belonging to the Maamora aquifer remains variable from one area to another depending on the geographical structure on the one hand and the exposure to the sources of anthropogenic pollution on the other hand.

From a bacteriological point of view, the groundwater in the city of Tiflet is polluted and does not meet drinking water standards. Thus, the concentration of fecal coliforms and fecal streptococci above 65 and $70 \mathrm{CFU} / 100 \mathrm{ml}$ with a source of fecal pollution of mixed origin predominantly animal.

This said, water disinfection is an essential step before any use.

However, from a physico-chemical point of view, these waters comply with Moroccan standards for water intended for human consumption, with $76 \%$, $90 \%$ and $88 \%$ of the wells studied not exceeding the maximum concentration standard for conductivity, turbidity and nitrates in drinking water respectively.

This groundwater complies with $100 \%$ of the physico-chemical parameters analysed and meets irrigation standards.

The comparison of the physico-chemical characteristics of the groundwater of the city of Tiflet shows a lower concentration by all parameters ( $\mathrm{pH}$, Conductivity, Turbidity, TH, TAC, MO, Sulfates, Nitrates and Phosphates) compared to other groundwater of different regions of Morocco (Taza, Martil, Settat, Mohammedia, Temara, Dar Bouazza, Tadla and the Central High Atlas). This can be explained on the one hand by a low rate of population and industrial activities and on the other hand by the depth of the groundwater and its permeability.

\section{References}

1. Louis, J.P., Trebucq,A., Gbadjaamo, M., Arrive,P., Foumane, V., Kalite,J., Rounegou,J.B. Childhood diarrhoeal diseases in Central African Republic, Black African Medicine, 38 (4) (1991).

2. WHO : Drinking Water Quality Guidelines; Volume 1-Recommendation. World Health Organization 2nd edition (1994).

3. Nimri,L.F., El Nasser,Z. et Batchoun, R.Polymicrobial infections in children with diarrhoea in a rural area of Jordan. FEMS Immunology and Medical Microbiology. 42, 255-259. (2004)

4. SWA : Sebou Watershed Agency Fès.

5. Michard A., Elements of Moroccan geology, Notes and Memoir. Serv. Geol. Rabat, Maroc, 252 (1976)

6. Master Plan for Integrated Water Resources Development of the Sebou river basin (2011)

7. Maâmora and Rharb Water Resources, Volume 2, Notes No. 231.

8. F Z. FAQIHIA, A. BENSLIMANEA, A. LAHRACHB, M. CHIBOUTA, M. EL MOKHTARC, Contribution to the analysis and mapping of hydrogeological data in the Kemisset Tiflet region (Morocco) by Geographic Information Systems (GIS), Journal of SAWIS, ISSN: 2351-9096, 29-32, (2015)

9. J .RODIER, B Legube, $\mathrm{N}$ Merlet et Collaborateurs, Water analysis, (2009).

10. Moroccan standard 03.7.001 quality of human feed water

11. Joint Order $n^{\circ} 1276-01$ setting standards for the quality of water intended for irrigation.

12. Ministry in charge of spatial planning, water and environment. State of Water Resources Quality in Morocco 2000/2001, 17 (November 2003).

13. Sawyer C. N., Mc Carty P L, Chemistry of Sanitary Engineers 2nd Edn., Mc Grow Hill, New York, 518 (1967).

14. J RODIER, C BAZIN, P BROUTIN, CHAMBON, H CHAMPSAUR et L RODI Water analysis, 8th edition. DUNOD (publisher), Paris, France, (1996).

15. $\mathrm{M} \mathrm{H}$ BENAJIBA, Y SAOUD, A LAMRIBAH, M AHRIKAT, N AMAJOUD ET O OULED-ZIAN, Assessment of the microbial quality of groundwater quality in Martil, Morocco/ Journal of Water Science, 26, 223-233 (2013). 
16. B ABBOU, M. El HAJI, M ZEMZAMI, FADIL, Determination of groundwater quality in groundwater tables in Taza province (Maroc), Larhyss Journal, 77-90 (2013)

17. M. LAAOUAN, M.A. ABOULHASSAN, S. BENGAMRA, A. TALEB, S. SOUABI, M. TAHIRI, Comparative study of three groundwater pollution cities of Mohammedia, Temara and Dar Bouazza by nitrates (Moroccan meseta), J. Mater. Environ. Sci. 7 (4) 1298-1309 (2016)

18. N E HAMMOUMI, M SINAN, B LEKHLIF et L E MAHJOUB, Groundwater quality assessment for drinking water and agricultural use: Tadla plain, Morocco, Africa SCIENCE 08 (1) 54 - 66 (2012).

19. N NOUAYTI, D KHATTACH, M HILALI, Assessment of physico-chemical quality of groundwater of the Jurassic aquifers in high basin of ZIZ (Central High Atlas, Morocco), J. Mater. Environ. Sci. 6 (4) 1068-1081 (2015)

20. J E ASSLOUJ, S KHOLTEI, N E AMRANIPAAZA et A HILALI, Impact of human activities on groundwater quality in the Mzamza community (Chaouia, Maroc), Journal of Water Science, $20 n^{\circ}$ 3, 309-321, (2007) 